\title{
Diversification and Environmental Impact Assessment of Plant Biomass Energy Use
}

\author{
Grzegorz Maj* \\ Department of Power Engineering and Transportation, University of Life Sciences in Lublin \\ Głęboka 28, 20-612 Lublin, Poland \\ Received: December 29, 2014 \\ Accepted: March 30, 2015
}

\begin{abstract}
This paper studies energy and environmental indicators of biomass in the form of vegetables as input resources, i.e. Virginia mallow, Miscanthus (x) giganteus, Jerusalem artichoke, prairie cordgrass, barley straw, wheat straw, rye straw, corn straw, rapeseed straw, meadow hay, and pine shavings. The study involved the measurement of physical and chemical properties, including the heat of combustion and calorific value of the input resources under consideration. It has been proven that pine shavings have the highest calorific value and that the heat of combustion amounts to $19.20 \mathrm{MJ} \cdot \mathrm{kg}^{-1}$ for calorific value and $17.85 \mathrm{MJ} \cdot \mathrm{kg}^{-1}$ for heat of combustion with moisture content of $7.23 \%$. The measurement of ash content has been the one of the main aims of the study. Jerusalem artichoke has posted the highest value at $14.69 \%$, and pine shavings the lowest at $0.85 \%$. An eco-balance of environmental impact of respective input resources has been developed by means of the EI environmental input indicator.
\end{abstract}

Keywords: biomass, energy, calorific value, ash, environmental input indicator

\section{Introduction}

Biomass is an environmentally friendly alternative energy source for the energy sector, which is more and more widely used by both individual electricity generators (distributed generation) and power engineering plants (power engineering industry) [1]. Energy produced from biomass is the least capital-intensive renewable energy source because of the optional self-contained production. 220 billion $\mathrm{Mg}$ of dry mass is obtained this way on an annual basis globally [2], and in Poland biomass output amounts to 15-20 million $\mathrm{Mg}$ of coal [3]. In the course of the biomass incineration process, i.e. conversion of the chemical energy contained in the biomass into thermal energy, $\mathrm{CO}_{2}$ emissions are counterbalanced by the quantity of the carbon dioxide absorbed by plants during growth $[2,4,5]$. Owing to this, there is a closed $\mathrm{CO}_{2}$ cycle in the natural environment that is contrary

*e-mail: grzegorz.maj@up.lublin.pl to the processing of fossil fuels to generate heat, in the case of which the quantity of the carbon dioxide emitted to the natural environment (as added value) is not counterbalanced in any way. The conversion of biomass is a renewable process and thus does not cause $\mathrm{CO}_{2}$ content to rise in the atmosphere and the greenhouse effect to increase [6-8].

Renewable energy sources contribute to environmental protection and mitigation measures against the adverse impact of the power engineering industry based on fossil fuels [9-11]. Lower content of ash and lower quantity of heavy metals released into the natural environment, owing to the use of biomass, accounts for the increasing popularity of this alternative energy source [12]. Reduction of emissions of hazardous substances into the atmosphere is currently necessary and is required by different international political and economic organizations [13]. The reduction of package emissions of harmful substances necessitates the search for new ecological solutions of production of different types of energy $[14,15]$. 
The aim of this paper is to give account of the energy and environmental indicators for biomass as an example of an alternative source of energy that is characteristic of high calorific value and environmentally friendly.

\section{Experimental}

\section{Material}

The study involved 11 crops divided into four groups. The first group consisted of four energy crops, i.e. Virginia mallow, Miscanthus (x) giganteus, Jerusalem artichoke, and prairie cordgrass. The second group of plants included crop residues in the form of: barley, wheat, rye, corn, and rape straws. Meadow hay constituted the third group of plants. Pine shavings, representing the fourth group, were adopted as the benchmark because they are the most commonly used crop for heating processes. The crops were chosen in such a way as to prove the differences in energy-giving properties between the specific energy crops, crop residues, meadow maintenance-related crops in the form of meadow hay, and the most widely used crop-derived fuel for the purpose of commercial and individual power generation, i.e. wood material.

The research input matter was collected at one time, i.e. in May, and subsequently stored in a storage facility for a period of two months before the commencement of the research, in order to stabilize the moisture content of the research input matter. Samples for testing purposes were taken twice a year, with the first annual sampling procedure conducted in summer (July-August) and the second annual sampling procedure was conducted in winter (JanuaryFebruary). The research input matter was stored in a closed storage facility of volatile temperature and humidity, which was to ensure natural environmental conditions (humidity) for the test samples. This aimed at reflecting real conditions of storage and demonstrating the impact of this factor upon the energy-giving properties of the research input matter.

\section{Methods}

The analysis of energy-giving properties of the research input matter involves the determination of moisture and ash content, the heat of combustion, and calculation of the calorific value. Basic information on the composition and utility properties of a given input matter is obtained on the basis of the analysis outcome. The moisture and ash content are a load measure in a fuel sample. Determination of the heat of combustion and the calorific value constitute the basis for assessing the quality of the energy crop. The research input matter underwent testing, including the determination of the analytical moisture, ash content, the heat of combustion, and calorific value.

The analytical moisture was determined by means of the gravimetric method in conformity with the PN/Z15008-02, PN/G-04511, and PN-EN 14774-1 standards [20-22]. Samples of the research input matter fragmented into a fraction below $0.5 \mathrm{~mm}$ in size and approximately $2 \mathrm{~g}$ in weight were put into glass weighing bottles and prepared for testing. The ready test samples were dried at an ambient temperature of $105^{\circ} \mathrm{C}$. The drying procedure was carried out by means of a POL-ECO SLN 32 ECO electric laboratory oven with natural air circulation. The drying procedure was carried out for 90 minutes. Next the glass bottle containing fuel was closed with a lid and removed from the oven, and after cooling down to ambient temperature it was weighed by means of an analytical balance. The drying procedure was repeated at intervals of 15 minutes until the weight was determined at $\pm 0.001 \mathrm{~g}$ accuracy.

The ash content was determined in accordance with the PN/G-04512 standard [23], which is in conformity with the PN-EN 14775 [24] for two combustion temperatures (i.e. $600^{\circ} \mathrm{C}$ and $815^{\circ} \mathrm{C}$ ) and two moisture levels depending on the time a sample was taken for testing. The research input matter was combusted in a Nabertherm L3/11/B180 muffle furnace. For research purposes a combustion temperature of $815^{\circ} \mathrm{C}$ was applied in conformity with the standards, which is the case with the low-ranked fuel such as biomass, peat, lignite, and geologically ('genetically') young hard coal. Due to the fact that the chemical composition of ash derived from biomass causes ash fusibility temperatures to be usually much lower than in the case of coals, sometimes the ash derived from biomass is liquid at $800^{\circ} \mathrm{C}$. This does not mean that the results are incorrect but that the crucible used for the determination of the ash content is lost. Thus, the second combustion temperature of $600^{\circ} \mathrm{C}$ was applied in order to compare the amount of ash obtained from the test samples, depending on the process temperature and to demonstrate possible differences. The research involved a complete combustion and annealing of an analytical fuel sample of $2 \mathrm{~g} \pm 0.1$ in weight, fragmented into fractions below $0.5 \mathrm{~mm}$ in size, in a muffle furnace heated up to the applicable temperature. The method of slow incineration was applied, where weighed samples in bottles were put into a cold muffle furnace and then heated in such a way that after 30 minutes the temperature inside the furnace reached $500^{\circ} \mathrm{C}$, and after subsequent $30-50$ minutes it reached the target-applicable temperature. The samples remained in the applicable process temperature for $90 \mathrm{~min}$ utes. Then the bottles with incinerated samples were removed from the furnace, cooled to ambient temperature, and weighed by means of an analytical balance. After cooling and weighing, the sample was calcined again for 15 minutes. This procedure was repeated until a constant weight was achieved.

Determination of the heat of combustion of the studied biomass for two moisture levels was carried out using the KL-12 calorimeter in accordance with the PKN-CEN/TS 14588 technical specification and the PN/G-04513 standard that is in conformity with PN-ISO 1928 [25-27]. According to the standards, the heat of combustion is the volume of heat obtained as a result of the combustion of a volume unit of solid fuel in the ambient air. Gases that are cooled down to the ambient temperature are the end-products of combustion; they include: oxygen, nitrogen, carbon dioxide, and sulphur dioxide, as well as water and ash. 
The calorific value was computed in conformity with the PN/G-04513 and PN-ISO 1928 standards using the relationship between the heat of combustion and the calorific value, according to which it is equal to the heat of combustion less the heat of water evaporation obtained from the fuel undergoing the combustion process and from hygroscopic moisture [26, 27].

The results obtained were subjected to statistical analysis performed using the Statistica 10 program. Estimation of the effect of moisture on the level of the heat of combustion and the calorific value was performed using Student's t-test. The effect of moisture and combustion temperature on the amount of ash obtained was estimated by means of ANOVA two-factor analysis of variance. All statistical analyses were performed at significance level of $\alpha=0.05$.

\section{Results and Discussion}

\section{The Output of Heat of Combustion and Calorific Value Study}

In the course of the study the calorific value and the heat of combustion of 11 different biomass input resources representing two moisture content values have been assessed. The study was carried out in the summer and winter. The input resources that underwent analysis in the summer is characterized by a lower moisture content in contrast to the input resources studied in the winter. The study output is shown in Figs. 1 and 2. Within the framework of the study, the value of the higher moisture content pertains to the winter while the value of the lower moisture content pertains to the summer.
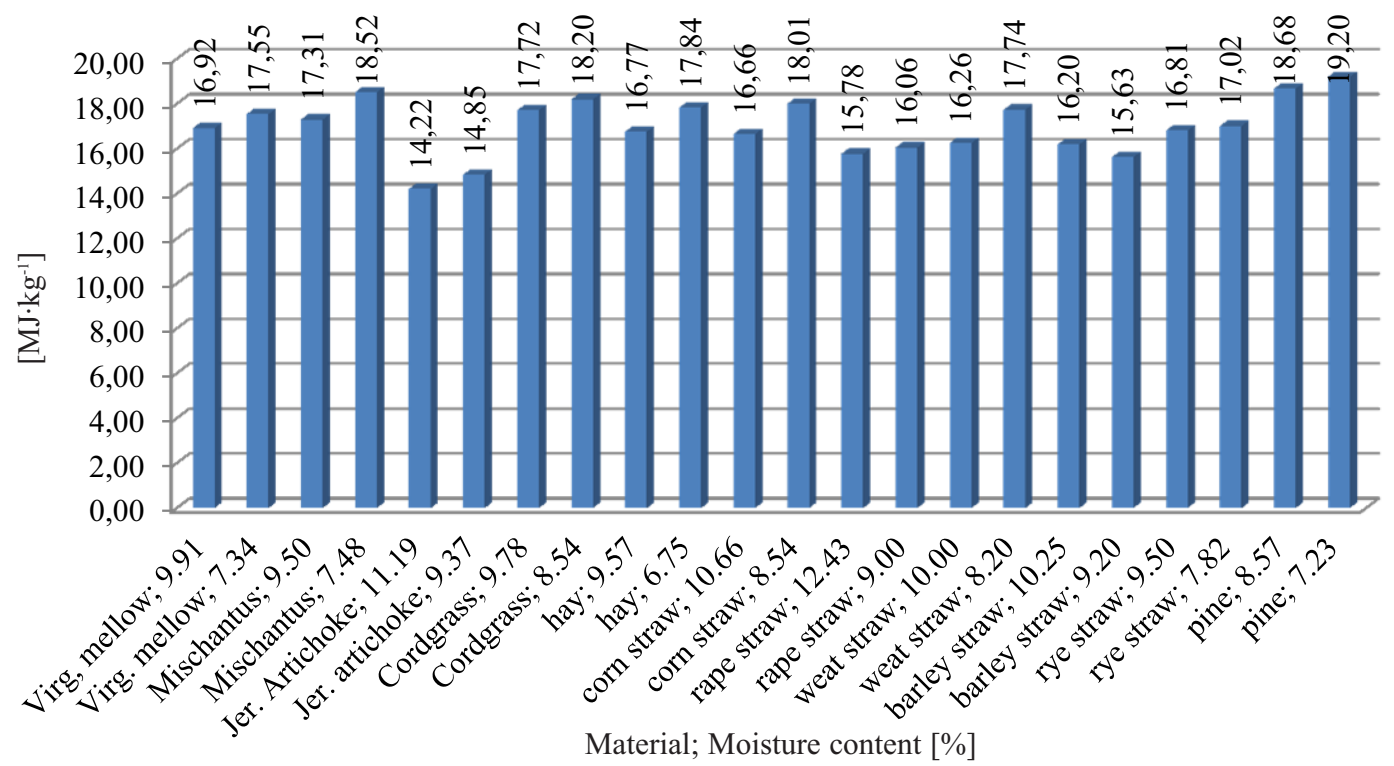

Fig. 1. The results of the heat of combustion of tested plant biomass for the two levels of moisture content.

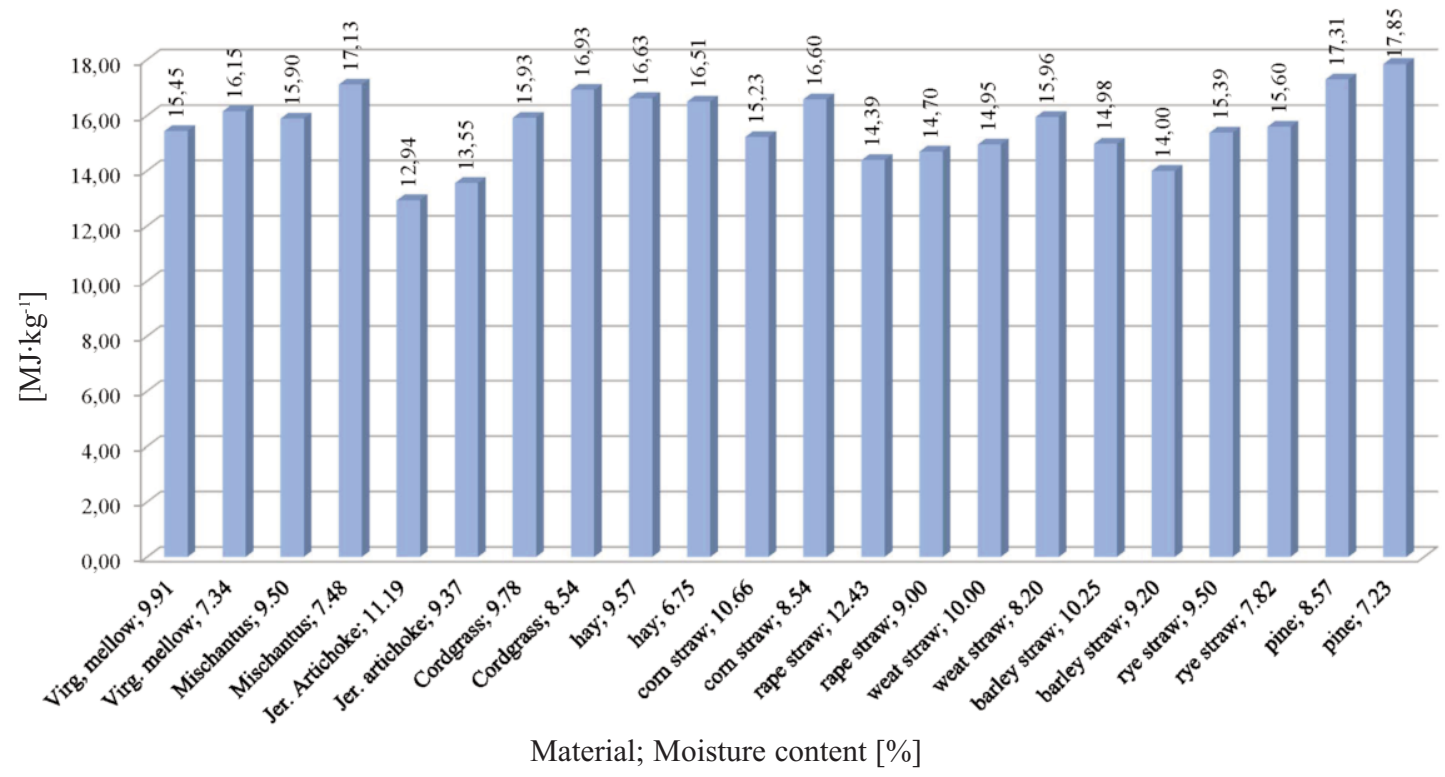

Fig. 2. The results of the calorific value of tested plant biomass for the two levels of moisture content. 
Table 1. Estimators of mean and variance for the heat of combustion and calorific value for Virginia mallow.

\begin{tabular}{|c|c|c|c|c|c|c|c|}
\hline \multirow{2}{*}{ Variable } & \multirow{2}{*}{ Moisture (\%) } & \multirow{2}{*}{$\mathrm{N}$} & \multirow{2}{*}{ Mean } & \multirow{2}{*}{ Std. Dev. } & \multicolumn{2}{|c|}{ Confidence interval } & \multirow{2}{*}{ Std. Err. } \\
\hline & & & & & For mean & For Std. Derv. & \\
\hline \multirow{3}{*}{$\begin{array}{l}\text { Calorific value } \\
\left(\mathrm{J} \cdot \mathrm{g}^{-1}\right)\end{array}$} & 7.34 & 6 & 16,154 & 129 & $16019 ; 16289$ & $80.524 ; 316.39$ & 52.66 \\
\hline & 9.91 & 6 & 15,448 & 74.574 & $15370 ; 15526$ & $46.55 ; 182.9$ & 30.44 \\
\hline & $\operatorname{Diff}(1-2)$ & & 705.85 & 105.36 & $570.31 ; 841.39$ & $73.619 ; 184.9$ & 60.83 \\
\hline \multirow{3}{*}{$\begin{array}{l}\text { Heat of } \\
\text { combustion } \\
\left(\mathrm{J} \cdot \mathrm{g}^{-1}\right)\end{array}$} & 7.34 & 6 & 17,547 & 129 & $17412 ; 17683$ & $80.52 ; 316.39$ & 52.66 \\
\hline & 9.91 & 6 & 16,920 & 74.574 & $16842 ; 16998$ & $46.55 ; 182.9$ & 30.44 \\
\hline & Diff (1-2) & & 627.4 & 105.36 & $491.86 ; 762.95$ & $73.61 ; 184.9$ & 60.83 \\
\hline
\end{tabular}

Table 2. t-Student test for equality of means for calorific value and heat of combustion for Virginia mallow.

\begin{tabular}{|c|c|c|c|}
\hline \multicolumn{4}{|c|}{ T-Test } \\
\hline Variable & DF & t Value & p-value \\
\hline Calorific value $\left({\left.\mathrm{J} \cdot \mathrm{g}^{-1}\right)}^{-10}\right.$ & 10 & 11.60 & $<.0001$ \\
\hline Heat of combustion $\left(\mathrm{J}^{-1}\right)$ & 10 & 10.31 & $<.0001$ \\
\hline
\end{tabular}

$\mathrm{DF}$ - degrees of freedom

The well-arranged resulting figures for the calorific value and the combustion heat of respective input resources in the summer within the framework of the study indicate that pine accounts for the highest values since the calorific value amounted to $19.20 \mathrm{MJ} \cdot \mathrm{kg}^{-1}$ and the heat of combustion amounted to $17.85 \mathrm{MJ} \cdot \mathrm{kg}^{-1}$, with $7.23 \%$ of the moisture content; as followed by Miscanthus (x) giganteus, prairie cordgrass, Virginia mallow, rye straw, meadow hay, corn straw, wheat straw, rapeseed straw, barley straw, and Jerusalem artichoke has accounted for the low- est value since the combustion heat amounted to 14.85 $\mathrm{MJ} \cdot \mathrm{kg}^{-1}$ and the calorific value was $13.55 \mathrm{MJ} \cdot \mathrm{kg}^{-1}$, with $9.37 \%$ of the moisture content. Whereas in the winter the pine shavings accounted for the highest combustion heat at $18.68 \mathrm{MJ} \cdot \mathrm{kg}^{-1}$ and the calorific value at $17.31 \mathrm{MJ} \cdot \mathrm{kg}^{-1}$, with $8.57 \%$ of the moisture content as followed by Miscanthus (x) giganteus, prairie cordgrass, meadow hay, corn straw, Virginia mallow, wheat straw, rye straw, barley straw, rapeseed straw, and Jerusalem artichoke accounting for the lowest combustion heat at $14.22 \mathrm{MJ} \cdot \mathrm{kg}^{-1}$ and calorific value of $12.94 \mathrm{MJ} \cdot \mathrm{kg}^{-1}$, with $11.19 \%$ of the moisture content.

The statistical analysis conducted in respect to the resulting figures for the combustion heat and calorific value has indicated that both influence the moisture content of Virginia mallow (Tables 1 and 2). The resulting figures for all remaining 10 input resources under consideration have turned out be the same.

Analysis of resulting figures indicates that as calorific value and combustion heat fall, moisture content rises for the input resources under consideration.

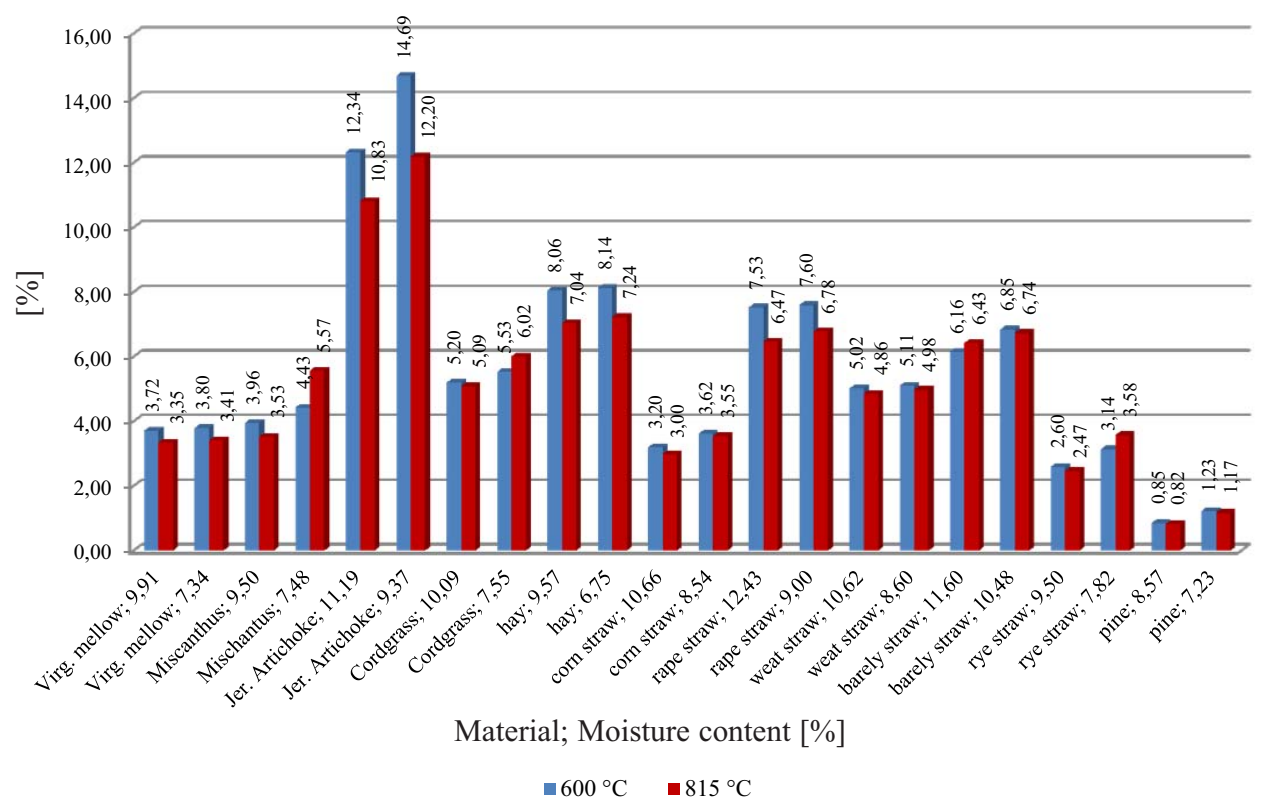

Fig. 3. The results of the ash content of the tested plant biomass, depending on combustion temperature and moisture content. 


\section{The Ash Content Resulting Figures}

The resulting figures for the ash content in 11 various biomass input resources in relation to the incineration temperature and two different moisture content values are shown in Fig. 3.

The resulting figures for the ash content in the relevant input resources indicate that in the summer season pine shavings account for the lowest ash content in relation to the incineration temperature at $600^{\circ} \mathrm{C}$, amounting to $0.85 \%$ and, in relation to the incineration temperature at $815^{\circ} \mathrm{C}$, to $0.82 \%$, with $7.23 \%$ of the moisture content, as followed by rye straw, corn straw, Virginia mallow, Miscanthus (x) giganteus, prairie cordgrass, wheat straw, barley straw, rapeseed straw, meadow hay, and Jerusalem artichoke accounted for in the season under consideration for the highest ash content in relation to the incineration temperature at $600^{\circ} \mathrm{C}$, to $12.34 \%$, and, in relation to an incineration temperature of $815^{\circ} \mathrm{C}$, to $10.83 \%$, with $9.37 \%$ of the moisture content. Whereas in the winter pine shavings have also accounted for the lowest ash content in relation to the incineration temperature at $600^{\circ} \mathrm{C}$, to $1.23 \%$, and, in relation to the incineration temperature at $815^{\circ} \mathrm{C}$, to $1.17 \%$, with $8.57 \%$ of the moisture content; as followed by rye straw, corn straw, Virginia mallow, Miscanthus (x) giganteus, wheat straw, prairie cordgrass barley straw, rapeseed straw, meadow hay, and Jerusalem artichoke, which account for the highest ash content in relation to the incineration temperature at $600^{\circ} \mathrm{C}$, to $14.69 \%$, and, in relation to the incineration temperature at $815^{\circ} \mathrm{C}$, to $12.20 \%$, with $11.19 \%$ of the moisture content.

The statistical ash content analysis has indicated that both the incineration temperature and moisture content have no influence on the ash content in Virginia mallow (Table 3). The resulting figures for all remaining 10 input resources are the same.

The variance analysis has indicated that there are no general tendencies accounting for the influence of the moisture content and incineration temperature upon ash content.

\section{The Eco-Balance Resulting Figures for Ash Content}

The outstanding issues connected with the assessment and valuation of the impact of fossil fuels and renewable energy sources upon the environment has been the subject matter of research for some time now [14, 16-18]. In Poland a vast number of the power engineering plants and distributed energy generation facilities continually use fossil fuels as the main source of energy, which is a clear reason for searching for unconventional energy sources that are environmentally friendly.

The so-called environmental input (EI) is used for assessing the aggregate impact of the power industry facilities upon the natural environment; it is a component of the quantity of the element, taking its source from the power industry and being released into the natural environment, and the volume characteristic for natural resources in respect to a category of input resources [19]:
Table 3. Results of analysis of variance for ash content, combustion temperature, and moisture content of the material for Virginia mallow.

\begin{tabular}{|c|c|c|c|c|c|}
\hline Source & DF & $\begin{array}{c}\text { Sum of } \\
\text { Squares }\end{array}$ & $\begin{array}{c}\text { Mean } \\
\text { Square }\end{array}$ & F Value & $\mathrm{p}$-value \\
\hline $\begin{array}{c}\text { Combustion } \\
\text { temperature }\end{array}$ & 1 & 0.808 & 0.808 & 125.58 & $<0.0001$ \\
\hline $\begin{array}{c}\text { Moisture } \\
\text { content }\end{array}$ & 1 & 0.025 & 0.025 & 3.89 & $<0.0001$ \\
\hline Error & 20 & 0.128 & 0.006 & & \\
\hline $\begin{array}{c}\text { Corrected } \\
\text { total }\end{array}$ & 22 & 0.962 & & & \\
\hline
\end{tabular}

DF - degrees of freedom

$$
\begin{aligned}
& E I=\frac{\sum \text { Amount of raw material }[\mathrm{Mg}]}{\text { Number of documented resource }} \\
& \text { of this resource }[\mathrm{Mg}]
\end{aligned}
$$

Development of the eco-balance contributes to the quantification of substances released into the natural environment and defines both the neutral and adverse impact of energy sources upon the natural environment.

On the grounds of computation Eq. 1, the eco-balance of environmental input for the ash content in relation to the incineration temperature at $600^{\circ} \mathrm{C}$ for the input resources under consideration is exhibited in Table 4.

This is the analysis of the ash content that is indicative of the energy source that has a specific impact upon the natural environment. The study has proven that pine shavings account for the smallest environmental impact for both moisture contents, whereas Jerusalem artichoke accounts for the highest environmental impact for two moisture content values. The environmental input indicators have been scrutinized in order to provide a reliable and credible source of information on the environmental impact of respective energy input resources.

\section{Conclusions}

Renewable energy sources protect the natural environment against the adverse impact of the fossil fuel-based power engineering industry. Reduction of emissions of hazardous substances into the atmosphere is needed and required by a variety of political and economic organizations all over the world. Reduction of package emissions of hazardous substances makes it necessary to search for new and environmentally friendly energy sources.

The environmental impact assessment indicators for respective energy sources contribute to the conscious inclination toward renewable energy sources, which in consequence is an environmentally friendly approach. The environmental input indicator analysis is indicative of the environmental impact of an input resource as compared to others, which is why it is so significant to conduct such an analysis for the purpose of assessing energy efficiency of input resources. Such analysis may have many components and it may be universally used for assessing energy sources. 
Table 4. Environmental input from ash content of tested material.

\begin{tabular}{|c|c|c|c|}
\hline Material & $\begin{array}{c}\text { Ash content } \\
{[\%]}\end{array}$ & $\begin{array}{c}\text { Moisture content } \\
{[\%]}\end{array}$ & EI \\
\hline \multirow{2}{*}{$\begin{array}{l}\text { Virginia } \\
\text { mallow }\end{array}$} & 3.80 & 9.91 & 38 \\
\hline & 3.72 & 7.34 & 33 \\
\hline \multirow{2}{*}{$\begin{array}{l}\text { Miscanthus } \\
\text { giganteus }\end{array}$} & 4.43 & 9.50 & 44 \\
\hline & 3.96 & 7.48 & 39 \\
\hline \multirow{2}{*}{$\begin{array}{l}\text { Jerusalem } \\
\text { artichoke }\end{array}$} & 14.69 & 11.19 & 145.8 \\
\hline & 12.34 & 9.37 & 123.2 \\
\hline \multirow{2}{*}{$\begin{array}{c}\text { Prairie } \\
\text { cordgrass }\end{array}$} & 5.53 & 9.78 & 49 \\
\hline & 5.20 & 8.54 & 56 \\
\hline \multirow{2}{*}{ Wheat straw } & 5.11 & 10.00 & 52 \\
\hline & 5.02 & 8.20 & 51 \\
\hline \multirow{2}{*}{ Barley straw } & 6.26 & 10.25 & 68 \\
\hline & 6.17 & 9.20 & 61 \\
\hline \multirow{2}{*}{ Rye straw } & 3.14 & 9.50 & 31 \\
\hline & 2.60 & 7.82 & 25 \\
\hline \multirow{2}{*}{ Rape straw } & 7.60 & 12.43 & 76 \\
\hline & 7.53 & 9.00 & 74 \\
\hline \multirow{2}{*}{ Corn straw } & 3.62 & 10.66 & 36 \\
\hline & 3.20 & 8.54 & 31 \\
\hline \multirow{2}{*}{ Hay } & 8.14 & 9.57 & 81 \\
\hline & 8.06 & 6.75 & 79 \\
\hline \multirow{2}{*}{ Pine shavings } & 1.23 & 8.57 & 12 \\
\hline & 0.85 & 7.23 & 8 \\
\hline
\end{tabular}

On the grounds of background and foreground knowledge, the following conclusions have been determined:

1. Statistical analysis of the resulting figures, given the error rate of $\alpha=0.05$, has been indicative of the significant influence of the moisture content in the biomass on combustion heat and calorific value. The higher the moisture content rises, the lower the combustion heat and calorific value fall.

2. Biomass is characteristic for the ash content that is lower than in the case of fossil fuel. Pine shavings account for the lowest ash content $(0.85 \%)$, whereas Jerusalem artichoke accounts for the highest ash content (14.69\%). This proves the good energy efficiency of the biomass.

3. The study has proven high combustion heat and calorific value of the energy sources under consideration in comparison with fossil fuel. This proves that the biomass at issue is an alternative energy source for the power engineering industry and distributed generation. Increasing the percentage share of renewable energy sources in the energy balance will allow for partial or total replacement of fossil fuel, which is currently the basic energy source for the power engineering industry and distributed generation, when fossil fuel is no longer available.

\section{References}

1. SAUTER P., WITT J., BILLIG E., THRÄN D. Impact of the Renewable Energy Sources Act in Germany on electricity produced with solid biofuels - Lessons learned by monitoring the market development. Biomass Bioenerg. 53, 162, 2013.

2. DZIEWANOWSKA M., DOBEK T. Analysis of the level of co and $\mathrm{CO}_{2}$ emission during the process of combustion of biomass containing leaves of various trees species. Acta Agrophysica 8, (1), 53, 2006 [In Polish].

3. KRÓL D., BORSUKIEWICZ-GOZDÓR A. Energy from sawmill and agricultural waste biomass. Archives of Waste Management and Environmental Protection 16, (3), 87, 2014.

4. NEY R. Solid fuels for power (coal, lignite, biomass). Way conference paper REE 2005, pp. 1-14, 2005 [In Polish].

5. SKIBA K., TYS A. Alternative sources of energy in the Lubelskie Province. Acta Agrophysica 14, (2), 449, 2009.

6. STOLARSKI M., SZCZUKOWSKI S., TWORKOWSKI J. Biofuels obtained from energetic perennials biomass. Energetyka 1, 77, 2008 [In Polish].

7. STRZELCZYK F., WAWSZCZAK A. The effectivity of the biomass as energy-fuel. Rynek Energii 5, 51, 2008 [In Polish].

8. SZYSZLAK-BARGŁOWICZ J., ZAJĄC G., PIEKARSKI W. Energy biomass characteristics of chosen plants. Int. Agrophys. 26, 175, 2012.

9. BASU P., BUTLER J., LEON M. A. Biomass co-firing options on the emission reduction and electricity generation costs in coal-fired power plants. Renew. Energ. 36, (1), 282, 2011.

10. SCHMIDT J., LEDUC S., DOTZAUER E., KINDERMANN G., SCHMID E. Cost-effective $\mathrm{CO}_{2}$ emission reduction through heat, power and biofuel production from woody biomass: A spatially explicit comparison of conversion technologies. Appl. Energ. 87, (7), 2128, 2010.

11. KHORSHIDI Z., HO M. T., WILEY D. E. The impact of biomass quality and quantity on the performance and economics of co-firing plants with and without $\mathrm{CO}_{2}$ capture. Int. J. of Greenhouse Gas Control 21, 191, 2014.

12. KALEMBKIEWICZ J., CHMIELARZ U. Effect of biomass Co-Combustion with Coal on Functional Speciation and Mobility of Heavy Metals in Industrial Ash. Pol. J. Environ. Stud. 22, (3), 741, 2013.

13. SPYRIDAKI N.-A., FLAMOS A. A paper trail of evaluation approaches to energy and climate policy interactions. Renew. Sust. Energ. Rev. 40, 1090, 2014.

14. PASSARINI F., NICOLETTI M., CIACCI L., VASSURA I., MORSELLI L. Environmental impact assessment of a WtE plant after structural upgrade measures. Waste Manage. 34, (4), 753, 2014.

15. PUPPAN D. Environmental evaluation of biofuels. Social and Management Sciences 10, (1), 95, 2002.

16. BROWN M. T., ULGIATI S., Emergy evaluations and environmental loading of electricity production systems. J. of Cleaner Production 10, (4), 321, 2002. 
17. REZAIE B., REDDY B. V., ROSEN M. A. An enviro-economic function for assessing energy resources for district energy systems. Energy 70, 159, 2014.

18. PIEKARSKI W. Renewable source of raw material for the production of energy and raw fuel depots (environmentally friendly). Inter. Sc. Conf.: Siedlce, pp. 24-29, 1996 [In Polish].

19. SZYSZLAK-BARGŁOWICZ J., SŁOWIK T., ZAJĄC G., PIEKARSKI W. Inline Plantation of Virginia mallow (Sida hermaphrodita R.) as Biological Acoustic Screen. Annual Set The Environment Protection 15, 524, 2013.

20. PN/Z-15008-02. Solid municipal wastes. Study of their properties as fuels. Determination of total moisture content, 1993 [In Polish].

21. PN/G-04511. Solid biofuels. Determination of moisture content, 1980 [In Polish].
22. PN-EN 14774-1. Solid biofuels. Determination of moisture content, 2010.

23. PN/G-04512. Solid biofuels. Determination of ash content with gravimetric method, 1980 [In Polish].

24. PN-EN 14775. Solid biofuels. Determination of ash content, 2010.

25. PKN-CEN/TS 14588. Solid biofuels. Terminology, definitions and terms, 2011.

26. PN/G-04513. Solid biofuels. Determination of heat of combustion and calculation of calorific value, 1981 [In Polish].

27. PN-ISO 1928. Solid fuels. Determination of heat of combustion with the method of combustion in calorimetric bomb and calculation of calorific value, 2002 [In Polish]. 
